\title{
Determinants of Behavioral Intention towards Mobile Learning in Pakistan: Mediating role of Attitude
}

\author{
Farhina Hameed ${ }^{1}$, Abdul Qayyum ${ }^{2}$
}

\begin{abstract}
Mobile learning is an emerging concept which has been verified in previous years. With the rapid advancement in mobile technology, it has emerged with new facets that have significant impact on attitude and behavioral intention towards mobile learning. The purpose of the study is to measure the factors that can affect the behavioral intention towards mobile learning in Pakistan. Mediating role of attitude and direct relationship of entertainment, informativeness and irritation are measured. Simple random sampling technique is applied to collect data from university students with a sample size of 373 individuals. Confirmatory factor analysis and multiple regression analysis are applied to measure model fitness and hypotheses. Whereas, dual statistical techniques i.e. Baron and Kenny's and Preacher and Hayes methods are applied to measure the mediation effect. All variables showed significant impact on behavioral intention towards mobile learning except irritation which exhibited partial mediation. Managerial,academic and future implications are also discussed.
\end{abstract}

Keywords: Attitude, behavioral intention, entertainment, irritation, mobile learning, Pakistan

\section{Introduction}

Mobile learning is at emerging phase in electronic learning and the notion has been verified in previous years (Hsu, Hwang, \& Chang, 2010). It is defined as "learning through mobile devices such as smart phones, tablets, MP3, MP4, and all other portable devices" (Toteja \& Kumar, 2013). Mobile learning is learning through multiple contexts, which provides flexible learning opportunities and widens the room for students and teachers. Consequently, mobile learning plays a significant role in education field by providing opportunities to its users, and has emerged as a prosperous drift with the expansion of mobile technologies. Out of various devices, mobile devices are one of the prime used technologies nowadays (Chuang \& Tsao, 2013).

1 PhD Scholar, SZABIST, Islamabad.Email: farhinahameed@yahoo.com

2 Assistant Professor, Riphah International University, Islamabad.

\begin{tabular}{|c|c|c|}
\hline \multicolumn{3}{|l|}{ ARTICLE HISTORY } \\
\hline 9 Oct, 2017 Submission Received & 16 Nov, 2017 & First Review \\
\hline 18 Dec, 2017 Revised Version Received & 2 Jan, 2018 & Second Review \\
\hline 8 Jan, 2018 Revised Version Received & 25 Jan, 2018 & Accepted \\
\hline
\end{tabular}


The prime advantage of mobile learning is the flow of information which is easy and fast. With the rapid advancement in mobile technology, students are using such devices for both communication and learning purposes (Pena-Ayala, Sossa, \& Mendez, 2014). Mobile learning has become the milestone of technology education and transformed society into a mobile society. It not only builds attitude but also generates positive behavioral intention that aids in learning context. Mobile devices have become necessary gadget in the modern lifestyle, as the number of mobile devices is expected to exceed the world population. It provides aid in learning context as compared to conventional system (Ozdamli \& Uzunboylu, 2015) the use of mobile technologies has increased in a number of fields such as banking, economy, tourism, entertainment, library research, etc. These developments have also led to the use of mobile technologies for educational purposes. The successful integration of mobile learning (m-learning. Previous studies have confirmed that learning at anywhere and anytime are only possible with mobile devices. Individuals who are in support of mobile learning are also in support of modern mobile technologies (Pena-Ayala et al., 2014).

The evolution of wireless communication and mobile technology has led the path towards mobile learning. It reduces the gap between students and students' learning material. It is mainly entertaining for the students as well as for teachers. Moreover, it provides recent and complete information but sometimes excess of information creates irritation among students (Hwang \& Chang, 2011).

Pakistan Telecommunication authority reveled that Teledensity is increasing annually. It was $4.2 \%$ in 2002 and $72.4 \%$ in 2017. With the rapid advancement in technology, broadband and internet services are also increasing (Pakistan Telecommunication Authority, 2017). The statistics points towards the immense success of mobile phone usage and versatility of mobile phones. In the same way, the trend of worldwide mobile phone usage is also increasing. In 2017, the number of mobile phone users are as 4.77 billion worldwide and mobile market is gaining popularity of smartphones. The number of smart phone users was 38\% in 2014 and is expected to reach over 50\% in 2018 (Number of mobile phone users worldwide from 2013 to 2019 , 2017). The reason behind using this technology is to stay updated and helps in getting hands-on education.

Mobile learning is the emerging trend in Pakistan and universities are also offering mobile education. These days, some of the universities have established separate departments which are offering mobile learning courses. Moreover, the traditional universities are also offering unconventional learning facilities to its students due to high demand and acceptability of it all over the world. The concepts of distance learning and mobile learning are inextricably linked and occasionally overlap in the domain of academic research. Distance learning initially refers to the access of learning 
material through external devices conventionally through course material available in conventional form or more recently online, accessible through computers and internet. Mobile learning extends this concept by allowing this access through hand held devices including mobile phones and tablets. For this study, unless explicitly mentioned, the distance learning will be used only in the context of mobile learning. In this study, mobile learning refers to the activities of learning with the usage of mobile devices amongst its students on a $24 / 7$ basis. The development in the technology has shifted the attitude of individuals which also varies from society to society. The study, as compared to other studies (Mohammadi, 2015a; Mohammadi, 2015b), is a step forward to measure the factors that can shape the attitude and behavioral intention towards mobile learning. The study is imperative in education sector because it tells the attitude and behavioral intention of students towards mobile learning. With the passage of time trend will be changing and the study helps to uncover the factors that may play important role in shaping attitude. Students are in better position to make difference between the conventional and unconventional studies and they can make strategies accordingly.

To explain this notion further, different models and theories have been used previously to determine the usage and acceptance level of individuals towards the technology but lacks theoretical background. It is the emerging paradigm in developing countries and needs to come up with factors that could influence behavioral intention towards mobile learning. There are various factors/antecedents available in literature (Ku, Chu, \& Tseng, 2013; Lin, 2014) that can affect the behavioral intention but the purpose of the current study is to evaluate the factors that can affect the behavioral intention towards mobile learning in Pakistan. However, the objective of the study is to measure the impact of entertainment, informativeness and irritation ( $\mathrm{Ha}, \mathrm{Kim}$, Libaque-Saenz, Chang, \& Park, 2015; Xu, Ryan, \& Prybutok, 2012) on attitude towards mobile learning and behavioral intention towards mobile learning as well as to measure the mediating effect of attitude in relation to aforementioned variables.

\section{Literature Review}

\subsection{Behavioral intention towards mobile learning}

Behavioral intention is defined as "an individual's subjective probability of performing specific conducts and is a major determinant of actual usage behavior" (Fishbein \& Ajzen, 1975, p. 288). Its relationship is based on theory of planned behavior (Taylor \& Todd, 1995). Intention is majorly caused by attitude and social norms. There is a positive relationship between behavioral intention and actual use of behavior. Intentions of users to adopt mobile learning is explained by (Tan, Ooi, Leong, \& Lin, B. 2014), fundamentally the elements that can affect the behavioral 
intentions. In previous literature, the relationship of behavioral intention with image, satisfaction in online retail and banking sector has been investigated. Mohammadi (2015a, b, c) examined various antecedents of mobile learning, user perspective of mobile learning in the presence of TAM, UTAUT and IS models and theories to measure the impact on behavioral intention and found significant effect. With the rapid advancement in mobile technology, mobile learning has emerged with new facets that have significant impact on attitude and behavioral intention (Wong, Wang, Ng, \& Kwan, 2015). Behavioral intention towards mobile learning is the emerging concept as explained by Alrasheedi, Capretz, and Raza (2015) the instructor perspective on mobile learning. It is the cutting edge platform mostly driven by smartphones and its usage is increasing in educational society day by day. It is the widely used technology of the modern world and due to the proliferation of technology, education sector is getting benefit. Different scholars have conducted researches to measure the critical success factors of mobile learning from student's perspective. Mobile learning is providing new techniques which are far beyond that offered by e-learning i.e. flexibility in terms of time and space. Thus, different operating systems such as, windows, android technology, blackberry, iOS system and many more not only facilitate individuals to surf on internet but these also facilitate and help students to access their learning material easily. Therefore, with the advancement in technology, learning system is also transformed.

\subsubsection{Entertainment}

McQuail (1983) explains entertainment as "the ability to fulfill an audience's needs for escapism, diversion, aesthetic enjoyment, or emotional enjoyment". Entertainment shapes the attitude of individuals that is basically considered as the indicator of behavioral intention (El-Garhi, 2014). There is a relationship between entertainment and experience that ultimately influence the attitude and entertainment has a significant relationship with attitude. Technology acceptance model (TAM) explains the intention to use numerous mobile services and its factors that explain which service is most entertaining for its customers (Kondo \& Ishida, 2014). It is more associated with the feeling of pleasure, when one has exposure to particular media and messages. Digital networks and electronic communication transformed the work and reshaped personal communication and entertainment and this transformation has tremendous effect on the need and opportunity to learn. In the teaching scenario, games and other activities are also included which described as an ancient art and today, it is considered as a primary way of communication and entertainment for students. It has a strong presence in all educational institutes in today's world. This approach increases the ability of students to learn and memorize things for long, by associating feeling with it as well as provides entertainment for learners. Mobile 
entertainment is also one of the important determinants in measuring the attitude and behavioral intention of students. Educational institutes conduct studies on investigating mobile entertainment that can have significant impact on behavioral intention. This technology allows learners to access learning material anywhere and anytime. It contributes to the success of students and at the same time increase the learning motivation among students (Wong et al., 2015).

\subsubsection{Informativeness}

Informativeness is defined as "the ability of advertising to inform consumers of product alternatives so that purchases yielding the greatest possible satisfaction can be made" (Ducoffe, 1996). The effect of informativeness on purchase intention has been studied and a significant relationship has been found among them. The information should be complete and accurate to make customers knowledgeable and it also helps in solving problems (Shim \& Youn, 2013). Entertainment and informativeness are two distinct properties that jointly effect online consumer behavior. It interacts with consumers and positively relates to purchase intentions and perceived value. In digital communications, informativeness is measured as a vital construct that have significant effect on attitude of individuals (Gvili \& Levy, 2016). Due to the rapid development of mobile devices and mobile internet usage, users can access wireless networks to browse information anytime, anywhere. The advertising industry can perform marketing through mobile advertising, and diversity can effectively improve the attractiveness of such advertising. According to the research findings, informativeness and credibility were major factors affecting the reuse intention of mobile advertising (Arli, 2017; Lin, Hsu \& Lin, 2017).

\subsubsection{Irritation}

Irritation refers to "the extent to which the web is messy and irritating to media users” (Eighmey \& McCord, 1998). Consumers feel frustrated and chaotic when they receive irritating messages which leads to the negative behavior of individuals that affect attitude and behavioral intention (Haq, 2009). Similar findings have been stated by El-Garhi (2014), that it is easy to control permission based advertising because it is under the control of consumers. Therefore, there is a relationship between irritation and attitude which leads towards behavioral intention. Hence, irritation is a phenomenon pretty much similar to reactance, where the consumer is more likely to reject advertisements perceived as intrusive. Perceived irritation has been illustrated to be dependent on numerous factors including number of messages, the frequency of ads, the messages content and their timings. It is an essential factor affecting mobile advertisement acceptance. The personal nature of the mobile can lead to the opposition of SMS advertising since it is potentially perceived as threatening consumers' 
privacy (Zedan \& Salem, 2016). Despite the proliferation of online shopping, irritation is determinant of behavioral intention. Irritation has significant negative effect on shopping behavior (Hasan, 2016). It distracts consumer attention and experiences and consumers figure out irritating stuff that leads to negative word of mouth.

The relationship of entertainment, informativeness and irritation is based on Uses \& Gratification theory (U\&G) (Katz, Blumler, \& Gurevitch, 1974). It is generally assumed that people always choose media by their choice and feel satisfaction because it results in positive attitude which is basically the indicator of behavioral intention (Ku et al., 2013). The theory is mainly used for studies including media, and mobile is media thus; it best explains its relationship (Reychav \& Wu, 2015).

\subsubsection{Attitude towards mobile learning}

Attitude is described as "the individual's positive or negative feelings about performing the behavior" (Fishbein \& Ajzen, 1975, p. 216). Its relationship is based on Theory of planned behavior (TPB). Literature showed certain factors which shape the attitude as well as behavioral intention of customers (Jung, Shim, Jin, \& Khang, 2015). Attitude, as a mediator, affect the behavioral intention of customers and literature supports its significant relationship with behavioral intention (Lin, 2014). Extensive review of literature has showed that attitude served as mediating variable and mediates the relationship between various independent and dependent variables (Curras-Perez, Ruiz-Mafe, \& Sanz-Blas, 2014; Zhu \& Chang, 2014). The findings of the study describe that informativeness and entertainment need is positively related to attitude to individuals that have significant impact on behavioral intentions. Attitude plays a significant mediating role in relationship between social networking sites and behavioral intentions (Jung et al., 2016). Moreover, various studies identified that attitude has significant and positive impact on behavioral intention towards mobile learning. In m-learning, the learner takes advantage of learning opportunities offered by mobile technologies. Students have showed positive attitude towards the use of e-learning and m-learning. Universities and educational institutes need to offer such learning opportunities to students.

The gap has been identified on the basis of extensive literature review mentioned below. Various typologies and antecedents have been used in previous literature to explore the effect on behavioral intention. Out of them entertainment, informativeness and irritation are the most prominent factors of Use \& Gratification theory. U\&G theory is previously used to explore web (Lim \& Ting, 2012), social networking sites such as Twitter, internet adoption for distance learning (Stafford, 2005), and virtual community use for learning (Mondi, Woods \& Rafi., 2008). As the study is about mobile learning, mobile is media thus, $U \& G$ is the best theory to explore mobile 
learning which has not been employed in this context yet. Various other theories and models have been explored previously in this regard though. However, there is a need to explore these factors (Ha et al., 2015; Ku et al., 2013). Moreover, as the usage of mobile devices is increasing therefore, there is a need to come up with factors that have potential effect on behavioral intention (Viberg \& Gronlung, 2013) specifically in the context of developing countries. Antecedents of Uses \& Gratification theory is not tested directly with behavioral intention in previous literature and suggestions from (Mohammadi, 2015c) are also incorporated to determine its effect. The study has been conducted in mobile learning context which is the untouched paradigm suggested by (Reychav \& Wu, 2015; Wong et al., 2015). Consequently, the study is an attempt to explore the factors that affect behavioral intention towards mobile learning. This segment has not received enormous attention and though it provides insight to media adoption and usage literature. It is the cutting edge platform mostly driven by smart phones and its usage is increasing in educational society day-by-day. It is the widely used technology of the modern world and due to the proliferation of technology; education sector is getting benefit from it.

\subsection{Hypotheses development}

H1: There is a positive and significant relationship between entertainment and attitude towards mobile learning.

$\mathrm{H} 2$ : There is a positive and significant relationship between informativeness and attitude towards mobile learning.

$\mathrm{H} 3$ : There is a negative and significant relationship between irritation and attitude towards mobile learning.

H4: There is a positive and significant relationship between entertainment and behavioral intention towards mobile learning.

H5: There is a positive and significant relationship between informativeness and behavioral intention towards mobile learning.

H6: There is a negative and significant relationship between irritation and behavioral intention towards mobile learning.

H7: There is a positive and significant relationship between attitude towards mobile learning and behavioral intention towards mobile learning.

H8: Attitude towards mobile learning mediates the relationship between entertainment and behavioral intention towards mobile learning.

H9: Attitude towards mobile learning mediates the relationship between infor- 


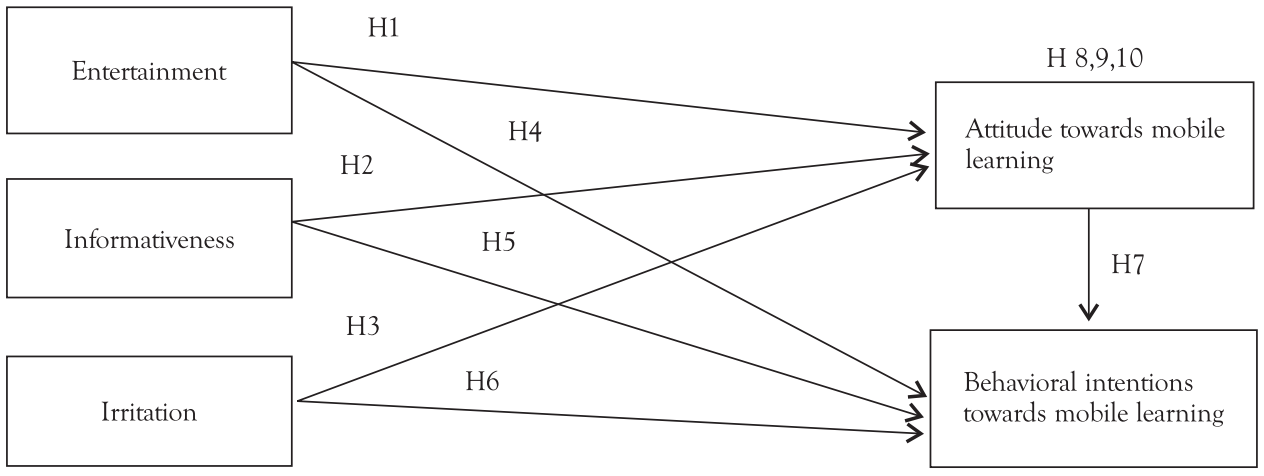

Figure 1: Conceptual model

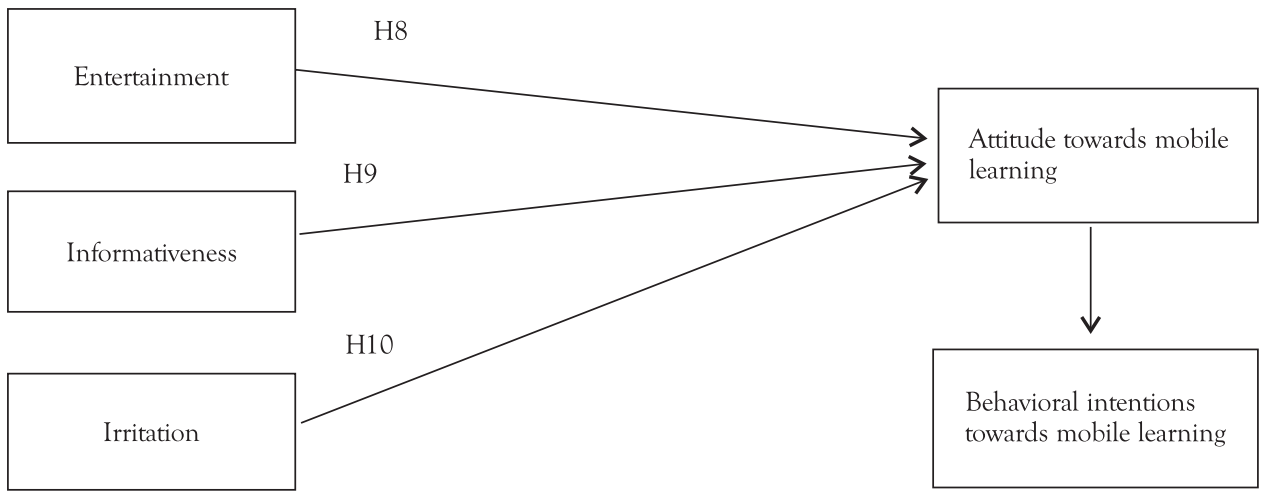

Figure 2: Conceptual model (Mediated Model)

mativeness and behavioral intention towards mobile learning.

H10: Attitude towards mobile learning mediates the relationship between irritation and behavioral intention towards mobile learning.

\section{Methodology}

The study is based upon positivism and deductive approach. It is causal in nature as cause and effect relationship of variables is explored. Adapted instrument has been used to collect data and responses were taken on five point Likert scales ranging from strongly disagree to strongly agree. There were total 24 items related to variables except 6 questions of demographics. 5 items of entertainment and irritation are adapted from (Chen \& Wells, 1999), 5 items of informativeness are adapted from (Korgaonkar \& Wolin, 1999), 4 items of attitude towards mobile learning are adapted from (Taylor \& Todd, 1995) and 5 items of behavioral intention towards mobile learning are adapted from (Gefen \& Straub, 2000). Population of the study is university students of twin cities i.e. Rawalpindi and Islamabad. Out of 18 renowned universities mentioned by 
$\mathrm{HEC}^{3}, 6$ universities have been selected randomly. It includes: COMSATS Institute of Information Technology, SZABIST Islamabad, Iqra University, Fatima Jinnah Women University, Arid Agriculture University and Quaid-i-Azam University Islamabad. Management Sciences Department of the mentioned institutes has been selected to collect data based on the similarity that all universities have Management Sciences Department and students have better knowledge of mobile learning and contemporary mobile technology. Simple random sampling has been applied to collect data after the permission from each university from the students of Management Sciences Department. Sample size is calculated on the basis of Krejcie and Morgan, (1970) formula. The population is approximately 10,000 students, enrolled in Management Sciences Department in all universities. The sample size comes out as 384 which is also confirmed by previous researches i.e. 390 (Mohammadi, 2015b; Mohammadi, 2015c), and the study took sample size of 450. Personally administered survey was conducted and questionnaires were floated among the classes and 434 returned back. 61 respondents who do not have smart phones and are not users of mobile devices are excluded from the study. There were total 373 usable responses. Response rate of the study is $82 \%$.

\section{Results}

SPSS-21 and AMOS-21 were used to execute the results. This section starts with description of demographics.

Demographic, Correlation, Reliability, Normality, Descriptive and Collinearity Statistics

Prior to peruse the actual analysis, the normality of the data has been checked and the value of Skewness and Kurtosis ranges between +1 and -1 thus, shows data is normally distributed. Linear Collinearity of data was measured via Variance Inflation Factor (VIF) and Tolerance Level. Tolerance level is not less than 0.01 and VIF is not greater than 10, thus shows Linear Collinearity of data. Reliability of data has been checked; value of Cronbach's alpha ranges between 0.77 to 0.87 for each construct thus, shows data is reliable. Mean and standard deviation shows that data is more inclined towards agree. Pearson Correlation is performed to check the association among variables of interest. The relationship between irritation and entertainment is negative as well as insignificant $(r=-0.053, \mathrm{p}>0.05)$.

\subsection{Confirmatory factor analysis (CFA)}

CFA is performed via AMOS-21 to measure how well items explain the constructs. To make the model fit better, modification indices has been applied from e20 to e22,

3 Higher Education Commission Pakistan,www.hec.gov.pk 
e20 to e23, e11 to e12, e12 to e15, e14 to e15, e1 to e2, e1 to e5, e4 to e5. Moreover, 1 item has been removed from construct informativeness as it has low item loadings.

There is a set of fit indices (Kline, 2005) which reflects the model fit and fit indices in Table 3, reflects that there is an overall good fit that supports model (Ryu, Ho, \& Han, 2003; Hair, Anderson, Tatham, \& Black, 1998).

All items have acceptable factor loadings thus unidimentionality has been achieved. Moreover, CFI of each construct also shows unidimentionality (Hair et al., 1998). Construct validity of study variables is evaluated by calculating the CR and AVE by using formula from Fornell and Larcker (1981) and Hameed (2013). Convergent validity exists when factor loadings are more than 0.50 , average variance extracted is greater than 0.5 and composite reliability is equal to or greater than 0.60 thus; study

Table 1: Demographics $(n=373)$

\begin{tabular}{|c|c|c|}
\hline \multicolumn{2}{|c|}{ Demographics } & \multirow{2}{*}{$\begin{array}{c}\text { Frequency } \\
159\end{array}$} \\
\hline Gender & Male & \\
\hline & Female & 214 \\
\hline \multirow[t]{4}{*}{ Age } & $15-25$ years & 299 \\
\hline & $26-35$ years & 57 \\
\hline & $36-45$ years & 12 \\
\hline & $46-55$ years & 5 \\
\hline \multirow[t]{4}{*}{ Education } & Bachelors & 292 \\
\hline & Masters & 50 \\
\hline & MS/Mphil & 28 \\
\hline & $\mathrm{PhD}$ & 3 \\
\hline \multirow[t]{2}{*}{ Smart phone } & Yes & 356 \\
\hline & No & 17 \\
\hline \multirow[t]{4}{*}{ Experience } & $<2$ years & 72 \\
\hline & $2-4$ years & 139 \\
\hline & 4-6 years & 105 \\
\hline & $>6$ years & 57 \\
\hline \multirow[t]{2}{*}{ Mobile devices } & Yes & 329 \\
\hline & No & 44 \\
\hline
\end{tabular}


Table 2: Correlation, Reliability, Normality, Descriptive and Collinearity Statistics $(n=373)$

\begin{tabular}{|c|c|c|c|c|c|}
\hline Constructs & ENT & INF & IRR & ATML & BITML \\
\hline ENT & 1 & & & & \\
\hline \multirow[t]{2}{*}{ INF } & $.443^{* *}$ & \multirow[t]{2}{*}{1} & & & \\
\hline & .000 & & & & \\
\hline \multirow[t]{2}{*}{ IRR } & -.053 & $-.118^{*}$ & \multirow[t]{2}{*}{1} & & \\
\hline & .306 & .023 & & & \\
\hline \multirow[t]{2}{*}{ ATML } & $.473^{* *}$ & $.375^{* *}$ & $-.103^{*}$ & \multirow[t]{2}{*}{1} & \\
\hline & .000 & .000 & .047 & & \\
\hline \multirow[t]{2}{*}{ BITML } & $.456^{* *}$ & $.373^{* *}$ & $-.111^{*}$ & $.691^{* *}$ & \multirow[t]{2}{*}{1} \\
\hline & .000 & .000 & .033 & .000 & \\
\hline Reliability & 0.849 & 0.772 & 0.879 & 0.795 & 0.847 \\
\hline Skewness & -.379 &. .953 & .349 &. .707 & -.666 \\
\hline Kurtosis & -.227 & 1.572 & -.477 & .587 & .480 \\
\hline Mean & 3.5094 & 3.8504 & 2.6906 & 3.6260 & 3.5845 \\
\hline St Dev & .84411 & .70546 & .94576 & .76850 & .79763 \\
\hline Tolerance & .676 & .754 & .980 & .486 & .494 \\
\hline VIF & 1.479 & 1.327 & 1.021 & 2.059 & 2.023 \\
\hline
\end{tabular}

Note: ENT=Entertainment, INF=Informativeness, $I R R=I$ rritation, $A T M L=$ Attitude towards mobile learning, BITML=Behavioral intention towards mobile learning

${ }^{* *}$. Correlation is significant at the 0.01 level (2-tailed). ${ }^{*}$. Correlation is significant at the 0.05 level (2-tailed).

confirms convergent validity (Awan \& Hameed, 2014). Discriminant validity exists when average variance extracted is higher than squared correlations; the value below 0.85 suggests discriminant validity. Thus, study exhibit discriminant validity (Hameed, Rehman \& Awan, 2016; Hameed \& Awan, 2017).

$$
P_{\text {com }}=\frac{\left[\left(\sum \lambda\right)\right]^{2}}{\left[\left(\sum \lambda\right)\right]^{2}+\left[\sum \theta\right]} \quad \text { Equation } 2
$$

Table 3: Model Fit

\begin{tabular}{|c|c|c|c|}
\hline Model fit measures & $\begin{array}{c}\text { Before applying modi- } \\
\text { fication (1) }\end{array}$ & $\begin{array}{c}\text { After applying modifi- } \\
\text { cation (2) }\end{array}$ & Recommended values \\
\hline CMIN/DF & 2.218 & 1.670 & $<3$ \\
\hline GFI & 0.88 & 0.922 & $>0.8$ \\
\hline CFI & 0.92 & 0.963 & $>0.9$ \\
\hline RMR & 0.049 & 0.042 & $<0.05$ \\
\hline RMSEA & 0.057 & 0.042 & $<0.06$ \\
\hline
\end{tabular}




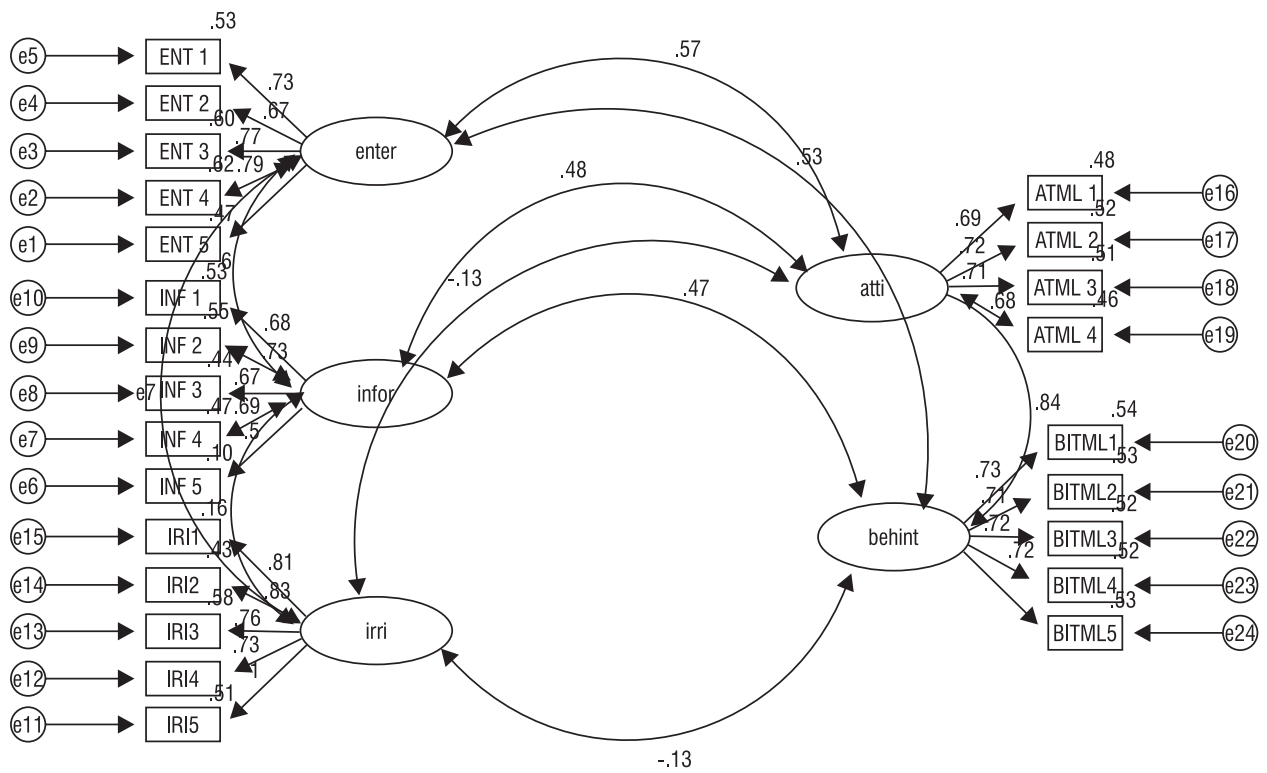

Figure 3: Measurement Model (1)

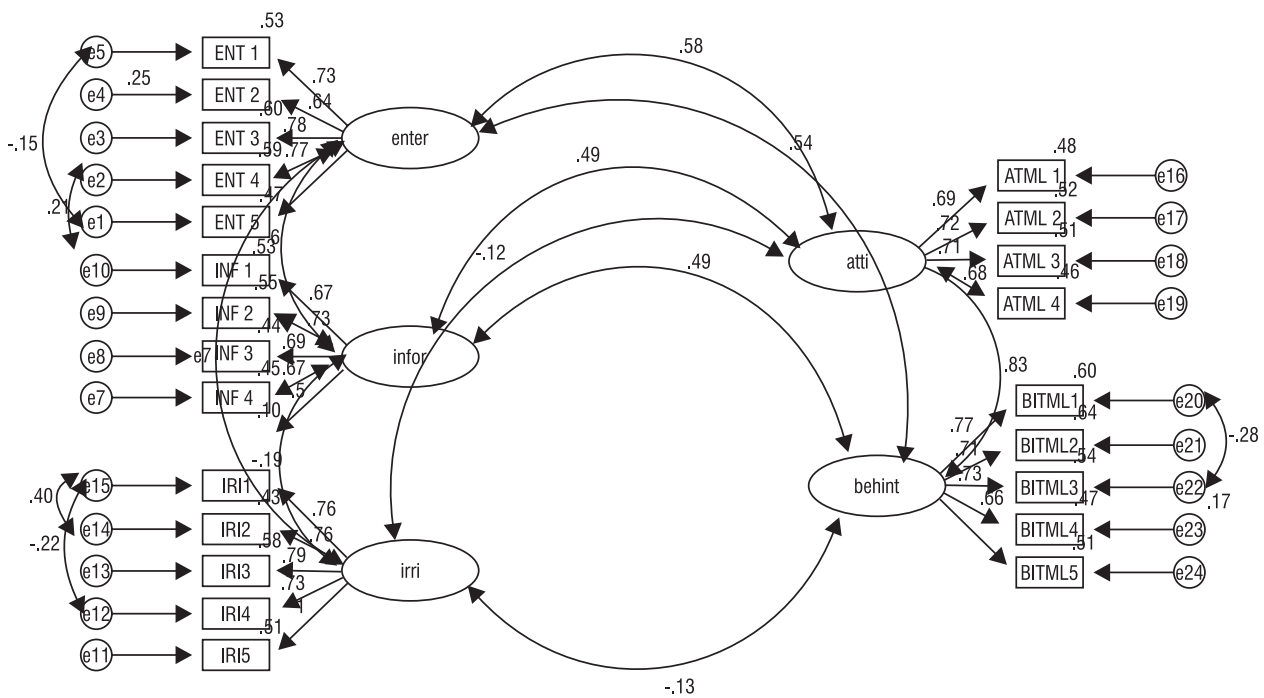

Figure 4: Re-specified Measurement Model (2)

$P_{\text {com }}=$ Composite Reliability

$\sum=$ Summation

$\lambda=$ Indicator's Standardized Loadings

$\lambda^{2}=$ Square of Indicator's Standardized Loadings 
Table 4: Confirmatory Factor Analysis (CFA) (n=373)

\begin{tabular}{|c|c|c|c|c|c|c|c|c|}
\hline $\begin{array}{l}\text { Con- } \\
\text { struct }\end{array}$ & $\begin{array}{l}\text { Factor } \\
\text { loadings }\end{array}$ & CFI & AVE & $\mathrm{CR}$ & Factors & $\begin{array}{c}\text { Factor } \\
\text { correla- } \\
\text { tion } \\
\end{array}$ & $\begin{array}{l}\text { Squared } \\
\text { correla- } \\
\text { tion }\left(\mathbf{r}^{2}\right)\end{array}$ & $\begin{array}{c}\text { AVE1 \& } \\
\text { AVE2 } \\
>\mathbf{r}^{2}\end{array}$ \\
\hline \multirow{5}{*}{ ENTER } & 0.725 & \multirow{5}{*}{0.99} & \multirow{5}{*}{0.51} & \multirow{5}{*}{0.84} & \multirow{3}{*}{$\begin{array}{c}\text { ENTER } \\
\langle\rightarrow \\
\text { INFO }\end{array}$} & \multirow{3}{*}{0.55} & \multirow{3}{*}{0.3025} & \multirow{5}{*}{$0.51-0.5$} \\
\hline & 0.64 & & & & & & & \\
\hline & 0.779 & & & & & & & \\
\hline & 0.771 & & & & \multirow{2}{*}{$\begin{array}{l}\text { ENTER } \\
<>\text { IRR }\end{array}$} & \multirow{2}{*}{-0.069} & \multirow{2}{*}{0.004761} & \\
\hline & 0.677 & & & & & & & \\
\hline \multirow[t]{5}{*}{ INF } & 0.67 & \multirow[t]{5}{*}{0.97} & \multirow[t]{5}{*}{0.50} & \multirow[t]{5}{*}{0.71} & \multirow{3}{*}{$\begin{array}{c}\text { ENTER } \\
< \\
>\text { ATML }\end{array}$} & \multirow[t]{3}{*}{0.538} & \multirow[t]{3}{*}{0.289444} & \multirow[t]{5}{*}{$0.51-0.5$} \\
\hline & 0.731 & & & & & & & \\
\hline & 0.685 & & & & & & & \\
\hline & 0.674 & & & & \multirow{2}{*}{$\begin{array}{c}\text { ENTER } \\
\Leftrightarrow \rightarrow \\
\text { BITML }\end{array}$} & \multirow[t]{2}{*}{-0.186} & \multirow[t]{2}{*}{0.034596} & \\
\hline & $\begin{array}{c}\text { Deleted } \\
\text { due to } \\
<0.40\end{array}$ & & & & & & & \\
\hline \multirow[t]{5}{*}{ IRR } & 0.761 & \multirow[t]{5}{*}{1.0} & \multirow[t]{5}{*}{0.57} & \multirow[t]{5}{*}{0.87} & \multirow{3}{*}{$\begin{array}{l}\text { INFO } \\
\langle->\text { IRR }\end{array}$} & \multirow[t]{3}{*}{0.49} & \multirow[t]{3}{*}{0.2401} & \multirow[t]{5}{*}{$0.51-0.5$} \\
\hline & 0.756 & & & & & & & \\
\hline & 0.791 & & & & & & & \\
\hline & 0.777 & & & & \multirow{2}{*}{$\begin{array}{c}\text { INFO } \\
<\rightarrow \\
\text { ATML } \\
\end{array}$} & \multirow[t]{2}{*}{0.486} & 0.236196 & \\
\hline & 0.712 & & & & & & & \\
\hline ATML & 0.699 & 0.97 & 0.5 & 0.79 & INFO & -0.123 & 0.015129 & $0.5-0.57$ \\
\hline & 0.72 & & & & $\begin{array}{c}\Leftrightarrow> \\
\text { BITML }\end{array}$ & & & \\
\hline & 0.713 & & & & IRR $\Longleftrightarrow$ & & & \\
\hline & 0.68 & & & & ATML & & & \\
\hline BITML & 0.775 & 0.98 & 0.72 & 0.84 & IRR $\longleftrightarrow$ > & -0.126 & 0.015876 & $0.5-0.5$ \\
\hline & 0.732 & & & & BITML & & & \\
\hline & 0.732 & & & & & & & $0.5-0.72$ \\
\hline & 0.683 & & & & ATML & 0.835 & 0.697225 & $0.57-0.5$ \\
\hline & 0.714 & & & & $\begin{array}{c}\longleftrightarrow> \\
\text { BITML }\end{array}$ & & & $\begin{array}{l}0.57- \\
0.72\end{array}$ \\
\hline
\end{tabular}


$\theta=\left(1-\lambda^{2}\right)$ Indicator Measurement Error

$P_{\text {ave }}==\frac{\left[\left(\sum \lambda^{2}\right)\right]}{\left[\left(\sum \lambda^{2}\right)_{+}\left[\sum \theta\right]\right.}$ Equation 3

$P_{\text {ave }}=$ Average Variance Extracted

$\sum=$ Summation

$\lambda^{2}=$ Square of Indicator's standardized loadings

$\theta=\left(1-\lambda^{2}\right)$ Indicator measurement error

\subsection{Hypotheses testing}

Multiple regression analysis was employed to measure the direct effect of entertainment, informativeness and irritation on attitude towards mobile learning $(\mathrm{H} 1$, $\mathrm{H} 2$, and $\mathrm{H} 3$ ). Table 5 shows $\mathrm{R}^{2}$ value as 0.26 thus $26 \%$ variation in attitude is caused by three predictors. 1 unit increase in entertainment and informativeness will cause $0.38,0.199$ increases in attitude. Entertainment has higher impact on attitude with $\beta=0.38$ hence, accepts $\mathrm{H} 1$ and $\mathrm{H} 2$. Whereas, irritation showed negative and insignificant impact on attitude. The correlation coefficient $r$ of irritation and attitude is also weak and negative $r=0.103 p<0.05$, thus rejects $\mathrm{H} 3$.

Table 5: Regression Analysis of ATML w.r.t ENT, INF and IRR ( $\mathrm{n}=373$ )

\begin{tabular}{|c|c|c|c|c|c|c|}
\hline Variables & $\mathrm{B}$ & $\mathrm{S} . \mathrm{E}$ & $\mathrm{B}$ & $\mathrm{t}$ & $\mathrm{R}^{2}$ & $\mathrm{~F}$ \\
\hline Constant & 6.800 & .942 & & 7.221 & & \\
\hline $\begin{array}{c}\text { Entertain- } \\
\text { ment }\end{array}$ & .278 & .036 & .382 & $7.664^{* *}$ & \multirow{2}{*}{0.26} & \multirow{2}{*}{$43.591^{* *}$} \\
\cline { 1 - 4 } $\begin{array}{c}\text { Informative- } \\
\text { ness }\end{array}$ & .173 & .044 & .199 & $3.963^{* *}$ & & \\
\hline Irritation &. .038 & .029 & .059 & -1.314 & & \\
\hline
\end{tabular}

${ }^{* *} \mathrm{p}<0.01$

Multiple regression analysis was employed to measure the direct effect of entertainment, informativeness and irritation on behavioral intention towards mobile learning ( $\mathrm{H} 4, \mathrm{H} 5$, and $\mathrm{H} 6)$. Table 6 shows $\mathrm{R}^{2}$ value as 0.24 thus $24 \%$ variation in behavioral intention is caused by three predictors. 1 unit increase in entertainment and informativeness will cause 0.36, 0.20 increases in behavioral intention. Entertainment has higher impact on attitude with $\beta=0.36$ hence, accepts $\mathrm{H} 4$ and $\mathrm{H} 5$. Whereas, irritation shows negative and insignificant effect on behavioral intention. 
The correlation coefficient $r$ of irritation and attitude is also weak and negative $r=$ $0.11 p<0.05$, thus rejects H6.

Table 6: Regression Analysis of BITML w.r.t ENT, INF and IRR ( $\mathrm{n}=373$ )

\begin{tabular}{|c|c|c|c|c|c|c|}
\hline Variables & $\mathrm{B}$ & $\mathrm{S} . \mathrm{E}$ & $\mathrm{B}$ & $\mathrm{t}$ & $\mathrm{R}^{2}$ & $\mathrm{~F}$ \\
\hline Constant & 8.227 & 1.232 & & 6.675 & & \\
\cline { 1 - 5 } $\begin{array}{c}\text { Entertain- } \\
\text { ment }\end{array}$ & .341 & .048 & .361 & $7.175^{* *}$ & \multirow{2}{*}{0.24} & \multirow{2}{*}{$40.711^{* *}$} \\
\cline { 1 - 4 } $\begin{array}{c}\text { Informative- } \\
\text { ness }\end{array}$ & .232 & .057 & .206 & $4.061^{* *}$ & & \\
\cline { 1 - 4 } Irritation &. .057 & .038 & .067 & -1.483 & & \\
\hline
\end{tabular}

${ }^{* *} \mathrm{p}<0.01$

Linear regression analysis was employed to measure the direct effect of attitude on behavioral intention towards mobile learning (H7). Table 7 shows $\mathrm{R}^{2}$ value as 0.47 thus $47 \%$ variation in behavioral intention is caused by attitude. 1 unit increase in attitude will cause 0.69 increase in behavioral intention thus accepts $\mathrm{H} 7$.

Table 7: Regression Analysis of ATML w.r.t BITML ( $\mathrm{n}=373$ )

\begin{tabular}{|c|c|c|c|c|c|c|}
\hline Variables & B & S.E & B & t & $\mathrm{R}^{2}$ & F \\
\hline Constant & 4.927 & 0.722 & & 6.822 & \multirow{2}{*}{0.47} & \multirow{2}{*}{$338.307^{* *}$} \\
\hline ATML & .896 & .049 & .0 .691 & $18.39^{* *}$ & & \\
\hline
\end{tabular}

${ }^{* *} \mathrm{p}<0.01$

\subsection{Mediation analysis}

Hypotheses 8, 9 and 10 states that attitude towards mobile learning mediates the relationship between entertainment, informativeness, irritation and behavioral intention towards mobile learning. According to Baron and Kenny (1986), three conditions must be fulfilled to carryout mediation. For H8, variation in entertainment significantly accounts for behavioral intention. Table 8 shows that Model-I confirms that the overall effect of entertainment on behavioral intention is statistically significant $\left(F=97.190, p<0.01, \beta=0.45, R^{2}=0.20\right)$. Second regression analysis is carried out to predict the effect of entertainment on attitude towards mobile learning. The results provide $\left(F=107.207, p<0.01, \beta=0.47, \mathrm{R}^{2}=0.22\right)$. Third regression analysis is performed in Model-III to predict behavioral intention from both entertainment and attitude, the results provide $\left(\mathrm{F}=214.374, p<0.01, \beta=0.61, \mathrm{R}^{2}=0.49\right)$. When entertainment and attitude are regressed together on behavioral intention in the third regression model, it is found that the regression coefficient $\beta$ significantly reduced 
from 0.45 to 0.16 , the value of $\mathrm{R}^{2}$ is increased from Model-I to Model-III 0.20 to 0.49. Based on change in $\beta$ values and $\Delta \mathrm{R}^{2}$, it is concluded that attitude towards mobile learning partially mediates the effects of entertainment on behavioral intention towards mobile learning, thus accepts $\mathrm{H} 8$.

Table 8: Mediation analysis of ATML between ENT and BITML ( $\mathrm{n}=373$ )

\begin{tabular}{|c|c|c|c|c|c|c|c|c|c|}
\hline Model & IV & DV & B & SE & $\beta$ & T & $\mathrm{R}^{2}$ & $\mathrm{~F}$ & $\Delta \mathrm{R}^{2}$ \\
\hline Model-I & ENT & BITML & .43 & .04 & .45 & $9.85^{* *}$ & .20 & $97.190^{* *}$ & - \\
\hline $\begin{array}{c}\text { Mod- } \\
\text { el-II }\end{array}$ & ENT & ATML & .34 & .03 & .47 & $10.34^{* *}$ & .22 & $107.207^{* *}$ & - \\
\hline \multirow{2}{*}{$\begin{array}{c}\text { Mod- } \\
\text { el-III }\end{array}$} & ENT & BITML & .15 & .04 & .16 & $3.96^{*}$ & .49 & $214.374^{* *}$ & .29 \\
\cline { 2 - 9 } & ATML & & .79 & .05 & .61 & $14.64^{* *}$ & & \\
\hline
\end{tabular}

${ }^{* *} \mathrm{p}<0.01$

Moreover, to increase the statistical power of mediation analysis, the study has applied Macro Process by Preacher and Hayes (2008) Model 4 using bootstrapping (Inman \& Nikolova, 2017). The technique of bootstrapping is well established in psychology research paradigm but in marketing research this technique is being accepted recently. The basic advantage of this method is simplicity which allows researcher to check the stability of results. Indirect effect is estimated on the basis of bootstrap samples generated from the original sample by random sampling with replacement. The present study repeat the bootstrapping procedure with 5000 samples (Hayes, 2008). The mediator is considered significant if the $95 \%$ confidence interval for the estimate of indirect effect does not include zero.

A path analysis was conducted to test the mediating effect of ATML between ENT and BITML. Results shown in Table 8.1 are based upon 5000 bootstrapped samples indicating that total effect $(.43, \mathrm{p}<.05)$ and indirect effect $(.27, \mathrm{p}<.05)$ is significant. The results indicate that ATML mediates the relationship between ENT and BITML (lower $95 \% \mathrm{CI}=.2046$ and upper $95 \% \mathrm{CI}=.3542)$. The direct effect $(.15, \mathrm{p}<.05)$ is also significant thus, shows partial mediation exists (Chang, Jeng, \& Hamid, 2013).

For $\mathrm{H} 9$, variation in informativeness significantly accounts for behavioral intention. Table 9 shows that Model-I confirms that the overall effect of informativeness on behavioral intention is statistically significant $\left(F=60.058, p<0.01, \beta=0.37, R^{2}\right.$ $=0.13)$. Second regression analysis is carried out to predict the effect of informativeness on attitude towards mobile learning. The results provide $(\mathrm{F}=60.712, p<0.01$, $\left.\beta=0.37, \mathrm{R}^{2}=0.14\right)$. Third regression analysis is performed in Model-III to predict behavioral intention from both informativeness and attitude, the results provide $(\mathrm{F}$ 
Table 8.1: Mediation Analysis of ATML between ENT and BITML by Process Macro $(\mathrm{N}=373)$

\begin{tabular}{|c|c|c|c|c|c|c|}
\hline \multirow[t]{2}{*}{ Path } & \multirow{2}{*}{$\begin{array}{c}\text { Total effect } \\
\text { IV-DV }\end{array}$} & \multirow{2}{*}{$\begin{array}{l}\begin{array}{l}\text { Direct } \\
\text { effect }\end{array} \\
\text { IV-DV }\end{array}$} & \multicolumn{2}{|c|}{ Indirect effect } & \multicolumn{2}{|c|}{$95 \% \mathrm{CI}$} \\
\hline & & & IV-M ${ }^{a}$ & $\mathrm{X} M-\mathrm{DV}{ }^{\mathrm{b}}$ & & \\
\hline & & & IV-Ma & M-DVb & Lower & Upper \\
\hline & & & & & Limit & Limit \\
\hline \multicolumn{3}{|c|}{ ENT-ATML-BITML } & \multicolumn{2}{|c|}{$.27(.03)$} & & \\
\hline & $.43(.04)$ & $.15(.03)$ & $.34(.02)$ & $.79(.05)$ & .2046 & .3542 \\
\hline
\end{tabular}

${ }^{*} \mathrm{R}$ square $=.49, \mathrm{~F}=183.730, \mathrm{p}<.05, \mathrm{n}=373$

*Bootstrap standard errors in parentheses

${ }^{*}$ Determined by bootstrapping with bias correction (5000 bootstrap)
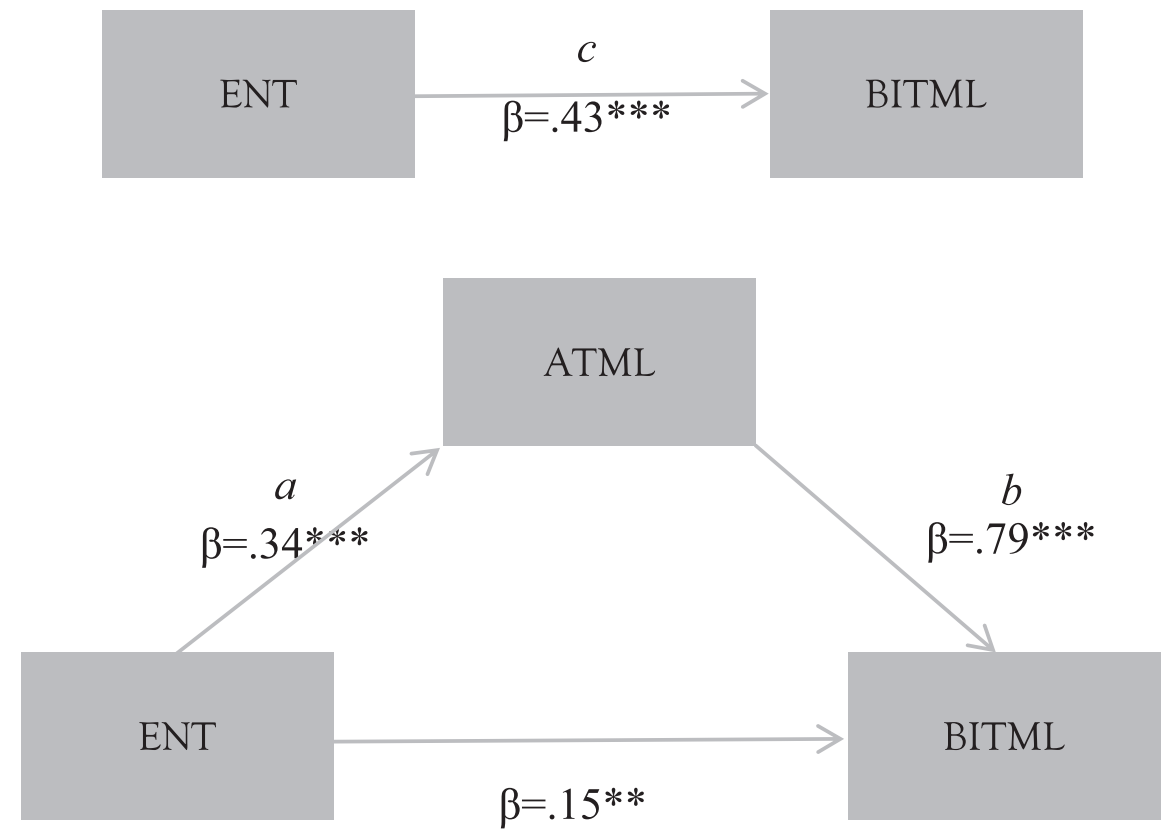

Figure 5: Mediated Model of ATML between ENT and BITML

$\left.=257.054, p<0.01, \beta=0.64, \mathrm{R}^{2}=0.48\right)$. When informativeness and attitude are regressed together on behavioral intention in the third regression model, it is found that the regression coefficient $\beta$ significantly reduced from 0.37 to 0.13 , the value of $\mathrm{R}^{2}$ is increased from Model-I to Model-III 0.13 to 0.48 . Based on change in $\beta$ values and $\Delta R^{2}$, it is concluded that attitude towards mobile learning partially mediates the effects of informativeness on behavioral intention thus, accepts $\mathrm{H} 9$. 
Table 9: Mediation analysis of ATML between INF and BITML ( $\mathrm{n}=373$ )

\begin{tabular}{|c|c|c|c|c|c|c|c|c|c|}
\hline Model & IV & DV & B & SE & $\beta$ & $\mathrm{T}$ & $\mathrm{R}^{2}$ & $\mathrm{~F}$ & $\Delta \mathrm{R}^{2}$ \\
\hline Model-I & INF & BITML & .42 & .05 & .37 & $7.75^{* *}$ & .13 & $60.058^{* *}$ & - \\
\hline $\begin{array}{c}\text { Mod- } \\
\text { el-II }\end{array}$ & INF & ATML & .32 & .04 & .37 & $7.79^{* *}$ & .14 & $60.712^{* *}$ & - \\
\hline \multirow{2}{*}{$\begin{array}{c}\text { Mod- } \\
\text { el-III }\end{array}$} & INF & BITML & .15 & .04 & .13 & $3.327^{*}$ & .48 & $257.054^{* *}$ & .35 \\
\cline { 2 - 10 } \cline { 4 - 9 } & ATML & & .83 & .05 & .64 & $16.03^{* *}$ & & & \\
\hline
\end{tabular}

${ }^{* *} \mathrm{p}<0.01$

A path analysis was conducted to test the mediating effect of ATML between INF and BITML. Results shown in Table 9.1 are based on 5000 bootstrapped samples indicating that total effect $(.42, \mathrm{p}<.05)$ and indirect effect $(.27, \mathrm{p}<.05)$ is significant. The results indicate that ATML mediates the relationship between INF and BITML (lower $95 \% \mathrm{CI}=.1796$ and upper $95 \% \mathrm{CI}=.3712)$. The direct effect $(.15, \mathrm{p}<.05)$ is also significant thus shows that partial mediation exists.

Table 9.1 Mediation Analysis of ATML between INF and BITML by Process Macro $(n=373)$

\begin{tabular}{|c|c|c|c|c|c|c|}
\hline \multirow[t]{2}{*}{ Path } & \multirow{2}{*}{$\begin{array}{c}\text { Total effect }{ }^{\mathrm{c}} \\
\text { IV-DV } \\
\end{array}$} & \multirow{2}{*}{ 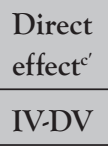 } & \multicolumn{2}{|c|}{ Indirect effect } & \multicolumn{2}{|c|}{$95 \% \mathrm{CI}$} \\
\hline & & & IV-Ma & $\mathrm{X} M-\mathrm{DV}{ }^{\mathrm{b}}$ & & \\
\hline & & & IV-Ma & $\mathrm{M}-\mathrm{DVb}$ & Lower & Upper \\
\hline & & & & & Limit & Limit \\
\hline \multicolumn{3}{|c|}{ INF-ATML-BITML } & \multicolumn{2}{|c|}{$.27(.04)$} & & \\
\hline & $.42(.05)$ & $.15(.04)$ & $.32(.04)$ & $.83(.05)$ & .1796 & .3712 \\
\hline
\end{tabular}

${ }^{*} \mathrm{R}$ square $=.49, \mathrm{~F}=179.2815, \mathrm{p}<.05, \mathrm{n}=373$

*Bootstrap standard errors in parentheses

*Determined by bootstrapping with bias correction (5000 bootstrap)

For $\mathrm{H} 10$, variation in irritation insignificantly accounts for behavioral intention. Table 10 shows that Model-I confirms that the overall effect of irritation on behavioral intention is statistically insignificant $\left(F=4.606, p<0.01, \beta=-.11, \mathrm{R}^{2}=.012\right)$. Second regression analysis is carried out to predict the effect of irritation on attitude towards mobile learning. The results provide $\left(F=3.967, p<0.01, \beta=-.10, \mathrm{R}^{2}=.011\right)$ which is also insignificant. As, assumptions are not fulfilled thus cannot run mediation and rejects $\mathrm{H} 10$. 

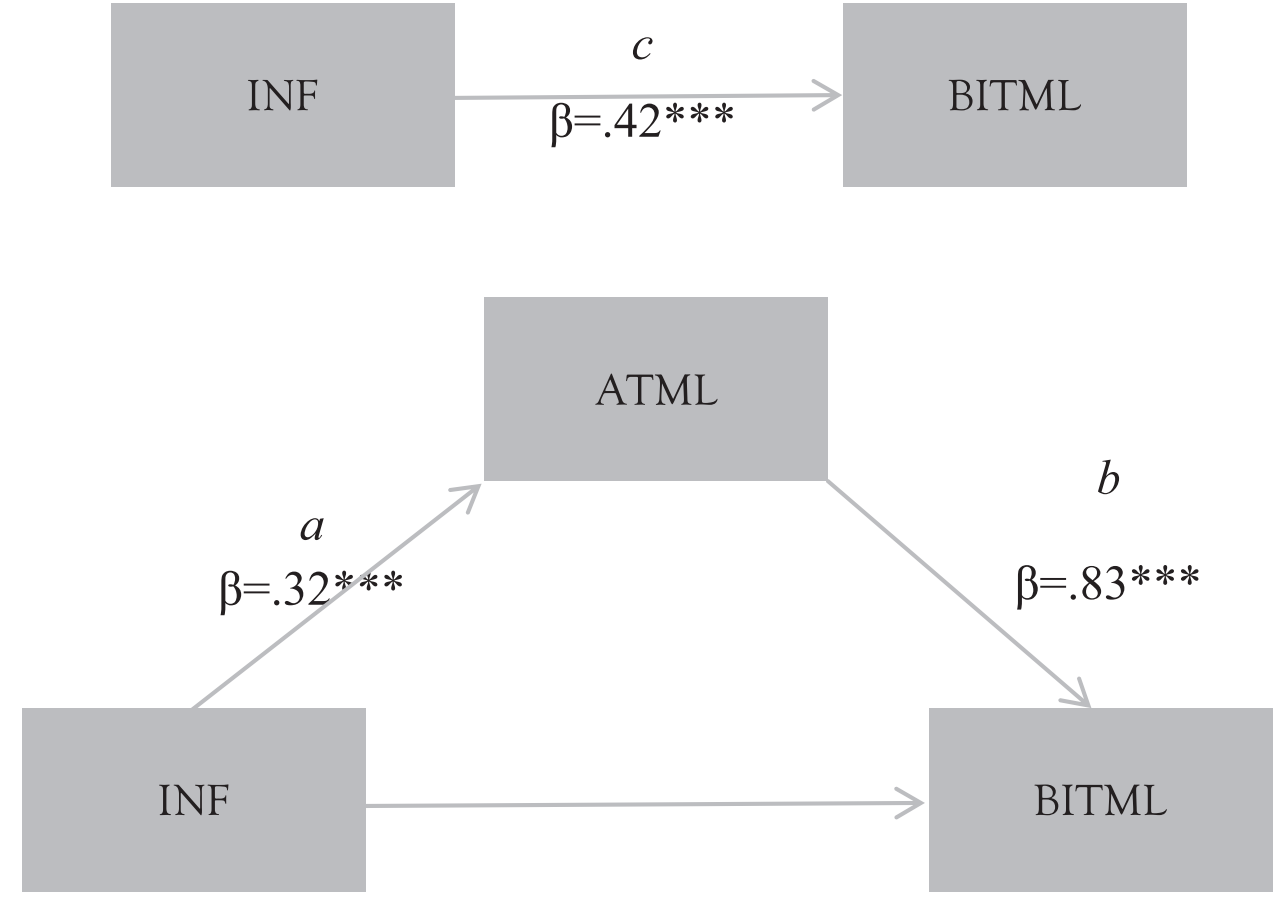

$$
\beta=.15^{* *}
$$

Figure 6: Mediated Model of ATML between INF and BITML

Table 10: Mediation analysis of ATML between IRR and BITML ( $\mathrm{n}=373$ )

\begin{tabular}{|c|c|c|c|c|c|c|c|c|c|}
\hline Model & IV & DV & B & SE & $\beta$ & $\mathrm{T}$ & $\mathrm{R}^{2}$ & $\mathrm{~F}$ & $\Delta \mathrm{R}^{2}$ \\
\hline Model-I & IRR & BITML & -.09 & .04 & -.11 & -2.146 & .012 & 4.606 & - \\
\hline $\begin{array}{l}\text { Mod- } \\
\text { el-II }\end{array}$ & IRR & ATML &. .06 & .03 & -.10 & -1.992 & .011 & 3.967 & - \\
\hline \multirow{2}{*}{$\begin{array}{l}\text { Mod- } \\
\text { el-III }\end{array}$} & IRR & \multirow[t]{2}{*}{ BITML } &. .03 & .03 & -.04 & -1.063 & \multirow[t]{2}{*}{.47} & 330.856 & .46 \\
\hline & ATML & & .89 & .04 & .686 & 18.18 & & & \\
\hline
\end{tabular}

${ }^{* *} \mathrm{p}<0.01$

A path analysis was conducted to test the mediating effect of ATML between IRR and BITML. Results shown in Table 10.1 are based on 5000 bootstrapped samples indicating that total effect $(-.09, \mathrm{p}<.05)$ and indirect effect $(-.05, \mathrm{p}>.05)$ is insignificant. The results indicate that ATML does not mediate the relationship between IRR and BITML (lower 95\% CI $=. .1309$ and upper 95\% CI= .0038). The direct effect (-.03, p>.05) is insignificant therefore, shows mediation does not exist. 
Table 10.1 Mediation Analysis of ATML between IRR and BITML by Process Macro $(n=373)$

\begin{tabular}{|c|c|c|c|c|c|c|}
\hline \multirow{2}{*}{ Path } & Total effect $^{\mathrm{c}}$ & $\begin{array}{c}\text { Direct } \\
\text { effect }\end{array}$ & \multicolumn{2}{c|}{ Indirect effect } & \multicolumn{2}{c|}{$95 \%$ CI } \\
\cline { 2 - 6 } & IV-DV & IV-DV & IV-M & X M-DV & \\
\hline \\
\hline
\end{tabular}

${ }^{*} \mathrm{R}$ square $=.47, \mathrm{~F}=169.7784 \mathrm{p}<.05, \mathrm{n}=373$

*Bootstrap standard errors in parentheses

${ }^{*}$ Determined by bootstrapping with bias correction (5000 bootstrap)
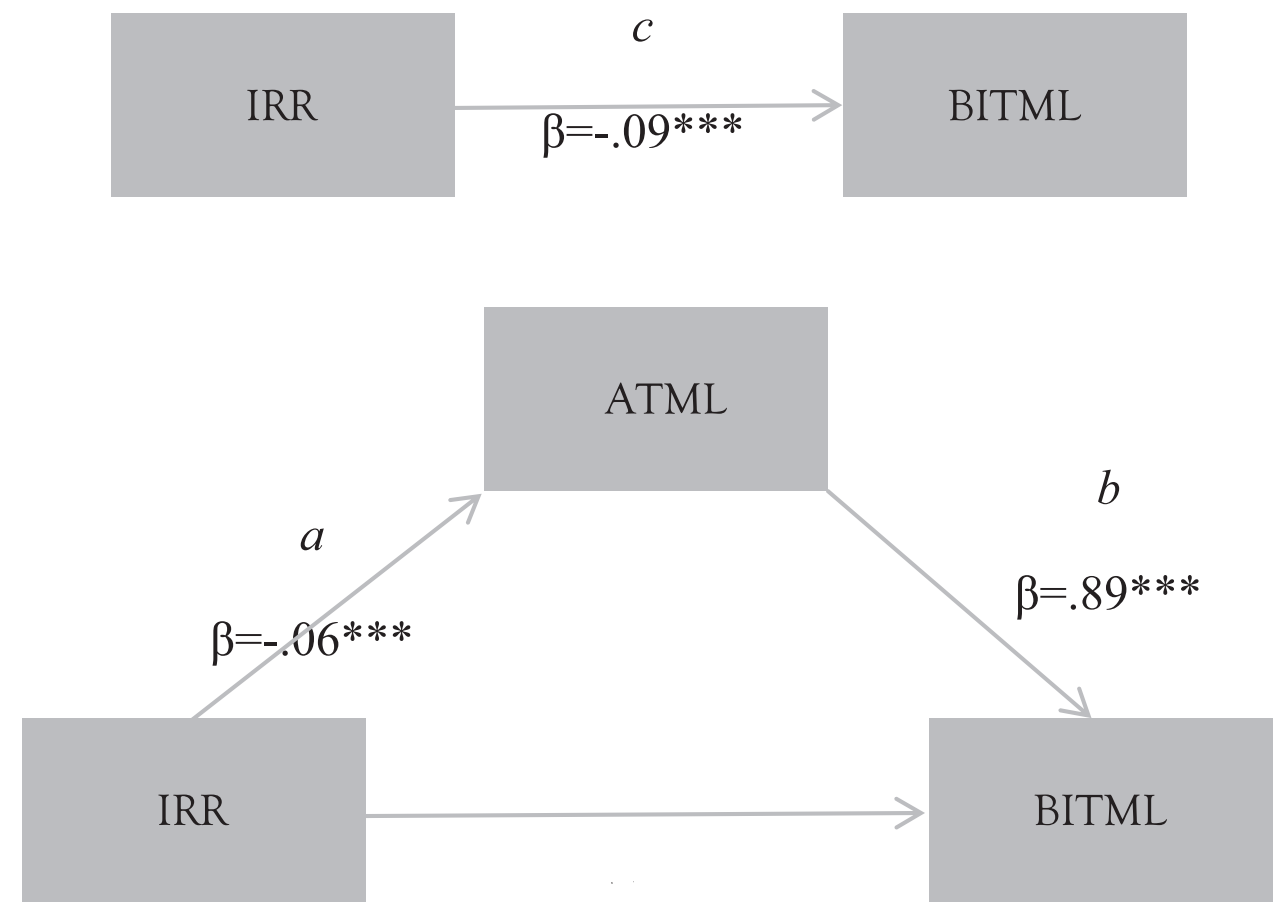

$$
\beta=-.03 * *
$$

Figure 7: Mediated Model of ATML between IRR and BITML 
Summary of Hypotheses

\begin{tabular}{|c|c|c|c|}
\hline No. & Hypotheses Statement & P value & Result \\
\hline $\mathrm{H} 1$ & $\begin{array}{l}\text { There is a positive and significant relationship between } \\
\text { entertainment and attitude towards mobile learning. }\end{array}$ & $\begin{array}{l}<0.01 \text {, signif- } \\
\text { icant }\end{array}$ & Supported \\
\hline $\mathrm{H} 2$ & $\begin{array}{l}\text { There is a positive and significant relationship between } \\
\text { informativeness and attitude towards mobile learning. }\end{array}$ & $\begin{array}{l}<0.01 \text {, signif- } \\
\text { icant }\end{array}$ & Supported \\
\hline $\mathrm{H} 3$ & $\begin{array}{l}\text { There is a negative and significant relationship between } \\
\text { irritation and attitude towards mobile learning. }\end{array}$ & $\begin{array}{l}>0.01, \text { insignif- } \\
\text { icant }\end{array}$ & Not supported \\
\hline $\mathrm{H} 4$ & $\begin{array}{l}\text { There is a positive and significant relationship between } \\
\text { entertainment and behavioral intention towards mobile } \\
\text { learning. }\end{array}$ & $\begin{array}{l}<0.01, \text { signif- } \\
\text { icant }\end{array}$ & Supported \\
\hline $\mathrm{H} 5$ & $\begin{array}{l}\text { There is a positive and significant relationship between } \\
\text { informativeness and behavioral intention towards } \\
\text { mobile learning. }\end{array}$ & $\begin{array}{l}<0.01 \text {, signif- } \\
\text { icant }\end{array}$ & Supported \\
\hline H6 & $\begin{array}{c}\text { There is a negative and significant relationship between } \\
\text { irritation and behavioral intention towards mobile } \\
\text { learning. }\end{array}$ & $\begin{array}{l}>0.01 \text {, insignif- } \\
\text { icant }\end{array}$ & Not supported \\
\hline $\mathrm{H} 7$ & $\begin{array}{l}\text { There is a positive and significant relationship between } \\
\text { attitude towards mobile learning and behavioral inten- } \\
\text { tion towards mobile learning. }\end{array}$ & $\begin{array}{l}<0.01, \text { signif- } \\
\text { icant }\end{array}$ & Supported \\
\hline $\mathrm{H} 8$ & $\begin{array}{l}\text { Attitude towards mobile learning mediates the relation- } \\
\text { ship between entertainment and behavioral intention } \\
\text { towards mobile learning. }\end{array}$ & $\begin{array}{l}<0.01, \text { signif- } \\
\text { icant }\end{array}$ & $\begin{array}{l}\text { Partial medi- } \\
\quad \text { ation }\end{array}$ \\
\hline H9 & $\begin{array}{l}\text { Attitude towards mobile learning mediates the relation- } \\
\text { ship between informativeness and behavioral intention } \\
\text { towards mobile learning. }\end{array}$ & $\begin{array}{l}<0.01, \text { signif- } \\
\text { icant }\end{array}$ & $\begin{array}{l}\text { Partial medi- } \\
\quad \text { ation }\end{array}$ \\
\hline $\mathrm{H} 10$ & $\begin{array}{l}\text { Attitude towards mobile learning mediates the rela- } \\
\text { tionship between irritation and behavioral intention } \\
\text { towards mobile learning. }\end{array}$ & $\begin{array}{l}>0.01 \text {, insignif- } \\
\text { icant }\end{array}$ & $\begin{array}{l}\text { Mediation is } \\
\text { not observed }\end{array}$ \\
\hline
\end{tabular}

\section{Discussion}

The objective of the study was to determine factors influencing behavioral intention towards mobile learning in Pakistan as well as to measure the influence of attitude as a mediator. The $U \& G$ theory is one of the prime theories in examining the relationship of various constructs with behavioral intention. Results of the current study have found significant and positive effect of entertainment on attitude as well as on behavioral intention towards mobile learning (El-Garhi, 2014). Entertainment not only shapes the attitude but also strengthens behavioral intention towards using particular brand/product. It is considered as vital feature for brand endorser and has 
positive relationship with brand attitudes (Kondo \& Ishida, 2014). Literature further supports the findings of the study that on attitude and behavior, the entertainment has positive and significant impact (Aslam, Batool, \& Ul Haq, 2016). Results also found positive and significant relation of informativeness with attitude and behavioral intention towards mobile learning. As the information is credible and complete, it leads towards building positive attitude and attitude is the indicator of behavioral intention (Shim \& Youn, 2013). Moreover, various researchers also identified the importance of informativeness and positive relationship among informativeness, attitude and behavioral intention (Haq, 2009) and it is measured as a vital construct for having a significant effect on attitude of individuals (Gvili \& Levy, 2016). Antecedents of positive user behavior were examined and the results exposed that informativeness is a key driver of favorable behavioral response and intention to involve in satisfactory user reactions which is positively related with intention to purchase (Jiang, Peng, \& Liu, 2015).

Moreover, irritation has negative and insignificant relationship with both attitude and behavioral intention. As long as people feel irritated, negative attitude builds which leads to negative behavioral intention. Customers have access to lots of information, due to which they feel irritated and find this information chaotic, and noisy (Reychav $\& \mathrm{Wu}, 2015)$. Due to the proliferation of technologies and media, the factor of irritation has increased which has negative effects on the attitude and behavioral intention (Hasan, 2016). Irritation is negatively associated with positive attitude and there are various reasons of possible annoyance i.e. unwanted and undesirable information that basically confuses the consumers and engage them in negative behavior (Haq, 2009). On the basis of said notion, insignificant relationship was found between attitude and behavioral intention. In present scenario, the findings of the study show that irritation has negative and insignificant effect on attitude towards mobile learning and behavioral intention towards mobile learning. This is because mobile learning is a new phenomenon in Pakistan and people do not associate irritation with mobile learning. Mobile learning is an emerging concept in developing countries which will take time to penetrate.

The development of technology in today's world is growing rapidly and there is need to use advanced technology in the field of education. Attitude towards mobile learning has positive and significant relationship with behavioral intention towards mobile learning. As attitude is the cause and indicator of behavioral intention, consumers having positive attitude, definitely exhibit positive behavioral intention (Jung et al., 2015). Positive behavioral intention also shows probability to have positive behavior in future. Results also found significant mediating role of attitude among entertainment and informativeness with behavioral intention and previous studies 
also supported its role as mediator (Lin, 2014). Attitude is equated with attitudinal belief, linking the beliefs with certain outcome and has positive effect on behavioral intention (Lee, 2009). Beliefs explains the attitude of individuals, however, limited number of beliefs are the determinants of attitude of individuals and it is found in literature that it has strong impact on behavioral intentions (Lee, Park, \& Han, 2011; Neuendorf, Xiong, Blake, \& Hudzinski, 2014; Ingham \& Cadieux, 2016). Attitude is the major determinant of behavioral intention (Akturan \& Tezcan, 2012).

Furthermore, findings of the study suggest that attitude does not mediate between irritation and behavioral intention towards mobile learning because it has insignificant impact. This is because mobile learning is at embryonic stage in Pakistan and people do not conceive it as an appropriate learning mode. However, it facilitates individuals even who are living far from conventional universities. It provides facilities to those students who cannot attend classes due to various reasons. Though, it is an emerging phenomenon around the globe and at very initial phase in Pakistan, students have showed positive attitude towards the use of e-learning and m-learning. It is, therefore required that the educational institutions offer such learning opportunities to students ( Park, Nam, Cha, 2012; Tuparov, Alsabri, \& Tuparova, 2015).

\subsection{Im plications}

The objective of study was to evaluate factors that have an effect on behavioral intention towards mobile learning. In the last decade, educational institutions are transformed in Pakistan due to the proliferation of technologies. These technological advancements have improved the learning abilities of students and have initiated occupying space in educational system of the country. Moreover, the use of technology i.e. android handsets and internet services is also increasing in Pakistan day-by-day. Thus, this study is helpful in evaluating the factors that play important role in making behavioral intention positive.

Conceptually, the study has number of contributions; firstly, the study has added attitude towards mobile learning as a mediator to measure the influence on behavioral intention towards mobile learning. Secondly, after extensive review of literature, the study came up with three predictors (entertainment, informativeness and irritation) that can play significant role in making positive behavioral intention. Thirdly, the study has developed a link of predictors with mediator and dependent variable both, in order to find out the true relationship. Lastly, the whole conceptual model is tested to measure the influence on behavioral intention towards mobile learning.

Methodologically, the study has various contributions. Firstly, dual method was used to measure the influence of mediator i.e. Baron \& Kenny and Preacher \& Hayes 
Macro. The reason behind using two methods was to reduce the potential problem with shared variance. Secondly, simple random sampling technique was used which is a type of probability sampling technique in order to generalize the research findings via using appropriate sampling procedure. Thirdly, plausibility of the research findings is investigated by keeping in view the past studies results. Lastly, Confirmatory Factor Analysis was employed to measure the construct validity. Moreover, construct validity was enhanced via using multi item measures.

Empirically, the study has numerous contributions. Firstly, the study extracted three factors from literature that could play significant role in making positive behavioral intention towards mobile learning. The findings of the study showed that two factors i.e. entertainment and informativeness have strong effect on attitude and behavioral intention towards mobile learning, while irritation has negative and insignificant impact. Secondly, theory of $U \& G$ has been explored in mobile learning context which was not earlier employed in this regard. Thirdly, role of mediator has been examined and attitude towards mobile learning came out as a strong mediator to cause positive behavioral intention.

From the standpoint of practical contribution, examination of behavioral intention towards mobile learning is valuable for policymakers, practitioners and institutions for devising strategies. The results of the study are helpful for examining the factors that play an important role in shaping the attitude and behavioral intention of the consumers. The educational institutions focus on those factors to demonstrate the importance of mobile learning which plays an imperative role in shaping the attitude and behavioral intentions. They should make strategies to attract the customers towards their institutions. Additionally, optimal strategies should be developed to reduce the irritation factor of the students that negatively affect the attitude and behavioral intentions. Moreover, the concept of mobile learning is associated with technology. This study is also helpful for telecom sector that they should come up with latest technology i.e. mobile phones, to facilitate customers. Internet should be provided either with fewer charges or free of cost to download the learning material from online sources. The study is also beneficial for companies who design laptops and portable gadgets which may help in accessing learning material should be convenient to carry, form one place to another.

Study exhibits number of limitations as data is collected only form students thus general public could be investigated further. Multiple regression analysis was employed to measure hypotheses and Structural Equation Modeling could be applied in future studies.

The study exhibits various future implications. Perceived trust and perceived value 
could be added to measure the behavioral intention towards mobile learning. The study was limited to behavioral intention; actual behavior can be studied in future though. Study can also be replicated in other domains to generalize the findings. As the study is cross sectional in nature, thus longitudinal study should be conducted in order to measure the actual behavior of students.

\section{References}

Akturan, U., \& Tezcan, N. (2012). Mobile banking adoption of the youth market: Perceptions and intentions. Marketing Intelligence $\mathcal{E}$ Planning, 30(4), 444-459.

Alrasheedi, M., Capretz, L. F., \& Raza, A. (2015). Instructor perspectives of mobile learning platform: An empirical study. International Journal of Computer Science and Information Technology, 7(3), 27-40.

Arli, D. (2017). Does social media matter? Investigating the effect of social media features on consumer attitudes. Journal of Promotion Management, 23(4), 521-539.

Aslam, W., Batool, M., \& Ul Haq, Z. (2016). Attitudes and behaviors of the mobile phones users towards SMS advertising: A study in an emerging economy. Journal of Management Sciences, 3(1), 63-80.

Awan, M. Y., \& Hameed, F. (2014). The effect of demographic, socio-economic and other characteristics on donations. Current Research Journal of Social Sciences, 6(2), 55-76.

Baron, R. M., \& Kenny, D. A. (1986). The moderator-mediator variable distinction in social psychological research: Conceptual, strategic, and statistical considerations. Journal of Personality and Social Psychology, 51(6), 1173.

Chen, Q., \& Wells, W. D. (1999). Attitude toward the site. Journal of Advertising Research, 39(5), 27-37.

Chuang, Y. H., \& Tsao, C. W. (2013). Enhancing nursing student's medication knowledge: The effect of learning materials delivered by short message service. Computers $\mathcal{E}$ Education, 61, 168-175.

Curras-Perez, R., Ruiz-Mafe, C., \& Sanz-Blas, S. (2014). Determinants of user behavior and recommendation in social networks: An integrative approach from the users and gratifications perspective. Industrial Management $\mathcal{E}$ Data Systems, 114(9), 1477-1498.

Ducoffe, R. H. (1996), Advertising value and advertising on the web, Journal of Advertising Research, $36(5), 21-35$.

Eighmey, J., \& McCord, M. (1998). Adding value in the information age: Uses \& gratifications of sites on the World Wide Web. Journal of Business Research, 41(3), 187-194.

El-Garhi, S. (2014). Consumer's attitude towards mobile advertisement: A study within the smartphone era among Ghanaian consumers. Bachelor's thesis submitted to the Department of Marketing, Halmstad University, Sweden.

Fishbein, M., \& Ajzen, I. (1975). Belief, attitude, intention $\mathcal{E}$ behavior: An introduction to theory and research. 
Addison-Wesley, California.

Fornell, C. \& Larcker, D. (1981). Evaluating structural equation models with unobservable variables and measurement error, Journal of Marketing Research, 18, 39-50.

Gefen, D., \& Straub, D. W. (2000). The relative importance of perceived ease of use in IS adoption: A study of e-commerce adoption. Journal of the Association for Information Systems, 1(1), 1-28.

Gvili, Y., \& Levy, S. (2016). Antecedents of attitudes toward eWOM communication: Differences across channels. Internet Research, 26(5), 1030-1051.

Ha, Y. W., Kim, J., Libaque-Saenz, C. F., Chang, Y., \& Park, M. C. (2015). Use and gratifications of mobile SNSs: Facebook and Kakao Talk in Korea. Telematics and Informatics, 32(3), 425-438.

Hair, J. F., Anderson, R. E., Tatham, R. L. \& Black, W. C. (1998). Multivariate data analysis withreadings. Prentice-Hall international, Englewood cliffs, NJ.

Hameed, F. (2013). The effect of advertising spending on brand loyalty mediated by store image, perceived quality and customer satisfaction: A case of hypermarkets. Asian Journal of Business Management, 5(1), 181-192.

Hameed, F., \& Awan, Y. (2017). Effect of dimensions of advertising on behavioral intentions of customers. Pakistan Business Review, 19(1), 138-156.

Hameed, F., Rehman, H., \& Awan, Y. (2016). Measuring the determinants of consumer perception regarding mobile advertising in Pakistan: a comparison between private and public sector universities. Science International, 28(1), 735-741.

Haq, Z. U. (2009). E-mail advertising: a study of consumer attitude toward e-mail advertising among Indian users. Journal of Retail \& Leisure Property, 8(3), 207-223.

Hasan, B. (2016). Perceived irritation in online shopping: The impact of website design characteristics. Computers in Human Behavior, 54, 224-230.

Hayes, A. F. (2008). Multiple mediation using bootstrapping in SPSS, 879-891.

Hsu, C. K., Hwang, G. J., \& Chang, C. K. (2010). Development of a reading material recommendation system based on a knowledge engineering approach. Computers $\mathcal{E}$ Education, 55, 76-83.

Hwang, G. J., \& Chang, H. F. (2011). A formative assessment-based mobile learning approach to improving the learning attitudes and achievements of students. Computers $\mathcal{E}$ Education, 56(4), 1023-1031.

Inman, J. J., \& Nikolova, H. (2017). Shopper-Facing retail technology: A retailer adoption decision framework incorporating shopper attitudes and privacy concerns. Journal of Retailing, 93(1), 7-28.

Ingham, J., \& Cadieux, J. (2016). From E-shopping system quality to the consumer's intention to return: A meta-analytic study of the mediation of attitude, usefulness, enjoyment, and trust. Proceedings of the Annual Hawaii International Conference on System Sciences, 2016-March, 3556-3564. 
Jiang, G., Peng, L., \& Liu, R. (2015). Mobile game adoption in china: The role of tam and perceived entertainment, cost, similarity and brand trust. International Journal of Hybrid Information Technology, 8(4), 213-232.

Jung, J., Shim, S. W., Jin, H. S., \& Khang, H. (2015). Factors affecting attitudes and behavioral intention towards social networking advertising: A case of Facebook users in South Korea. International Journal of Advertising, 35(2), 1-18.

Katz, E., Blumler, J. G., \& Gurevitch, M. (1974). Utilization of mass communication by the individual. In J. G. Blumler \& E. Katz (Eds.), The uses of mass communication: Current perspectives on gratifications research. (pp. 19-31). Sage Publications, Beverly Hills, CA.

Kline, R. B. (2005). Principles and practice of structural equation modeling (2nd ed.). New York: The Guilford Press.

Kondo, F. N., \& Ishida, H. (2014). A cross-national analysis of intention to use multiple mobile entertainment services. Journal of Global Information Technology Management, 17(1), 45-60.

Korgaonkar, P. K., \& Wolin, L. D. (1999). A multivariate analysis of web usage. Journal of Advertising Research, 39(2), 53-68.

Krejcie, R. V., \& Morgan, D. W. (1970). Determining sample size for research activities. Educational and Psychological Measurement, 30(3), 607-610.

Ku, Y.C., Chu, T. H., \& Tseng, C. H. (2013). Gratifications for using CMC technologies: A comparison among SNS, IM, and e-mail. Computer Human Behavior, 29(1), 226-234.

Lee, M. C. (2009). Factors influencing the adoption of internet banking: An integration of TAM and TPB with perceived risk and perceived benefit. Electronic Commerce Research and Applications, 8(3), $130-141$.

Lee, J., Park, D., \& Han, I. (2011). The different effects of online consumer reviews on consumers' purchase intentions depending on trust in online shopping malls. Internet Research, 21(2), 187-206.

Lim, W. M., \& Ting, D. H. (2012). E-shopping: An analysis of the uses and gratifications theory. Modern Applied Science, 6(5), 48-63.

Lin, C.-W., Hsu, Y.-C., \& Lin, C.Y. (2017). User perception, intention, and attitude on mobile advertising. International Journal of Mobile Communications, 15(1), 104-117.

Lin, J. (2014). The effects of gratifications on intention to read citizen journalism news: The mediating effect of attitude. Computers in Human Behavior, 36, 129-137.

McQuail, D. (1983). Mass communication theory: An introduction. London: Sage.

Mohammadi, H. (2015a). A study of mobile banking loyalty in Iran. Computers in Human Behavior, 44, $35-47$. 
Mohammadi, H. (2015b). Factors affecting the e-learning outcomes: An integration of TAM and IS success model. Telematics and Informatics, 32(4), 701-719.

Mohammadi, H. (2015c). Investigating user's perspectives on e-learning: An integration of TAM and IS success model. Computers in Human Behavior, 45, 359-374.

Mohammadi, H. (2015d). Social and individual antecedents of m-learning adoption in Iran. Computers in Human Behavior, 49, 191-207.

Mondi, M., Woods, P. \& Rafi, A. (2008). A uses and gratification expectancy model to predict student's perceived learning experience. Educational Technology $\mathcal{E}$ Society, 11(2), 241-261.

Neuendorf, K., Xiong, C., Blake, B., \& Hudzinski, K. (2014). Need for presence, enjoyment, and attitude toward vendor: Predicting purchase intent in the online shopping environment. Retrieved from: file://C:/ Users/Research/Downloads/NeuendorfXiongetal14.pdf

Ozdamli, F., \& Uzunboylu, H. (2015). M-learning adequacy and perceptions of students and teachers in secondary schools. British Journal of Educational Technology, 46(1), 159-172.

Park, S.Y.; Nam, M.; Cha, S. (2012). University students' behavioral intention to use mobile learning: Evaluating the technology acceptance model. British Journal of Educational Technology, 43(4), 592-605.

Pena-Ayala, A., Sossa, H., \& Mendez, I. (2014). Activity theory as a framework for building adaptive e-learning systems: A case to provide empirical evidence. Computers in Human Behavior, 30, 131-145.

Preacher, K. J., \& Hayes, A. F. (2008). Asymptotic and resampling strategies for assessing and comparing indirect effects in multiple mediator models. Behavior Research Methods, 40(3), 879-891.

Reychav, I., \& Wu, D. (2015). Are your users actively involved? A cognitive absorption perspective in mobile training. Computers in Human Behavior, 44, 335-346.

Ryu, S., Ho, S. H., \& Han, I. (2003). Knowledge sharing behavior of physicians in hospitals, Expert Systems with Application, 25, 113-122.

Shim, K. Y., \& Youn, M. K. (2013). Mediating effect of informativeness joyfulness and trust in internet shopping mall's image on consumer's purchase intention. Journal of Convergence Information Technology, 8(14), 205.

Stafford, T. F. (2005). Understanding motivations for internet use in distance education. IEEE Transactions on Education, 48(2), 301-307.

Tan, G. W. H., Ooi, K. B., Leong, L. Y., \& Lin, B. (2014). Predicting the drivers of behavioral intention to use mobile learning: A hybrid SEM-Neural networks approach. Computers in Human Behavior, 36, 198-213.

Taylor, S., \& Todd, P. (1995). Assessing IT Usage: The Role of Prior Experience, MIS Quarterly, 19(4), 561-570. 
Toteja, R., \& Kumar, S. (2013). Usefulness of M-devices in education: A survey. Procedia-Social and Behavioral Sciences, 67, 538-544.

Tuparov, G., Alsabri, A. A. A., \& Tuparova, D. (2015). Students' readiness for mobile learning in Republic of Yemen - A pilot study. Proceedings of 2015 International Conference on Interactive Mobile Communication Technologies and Learning, IMCL 2015, (November), 190-194.

Viberg, O., \& Gronlung, A. (2013). Cross-cultural analysis of user's attitude toward the use of mobile devices in second and foreign language learning in higher education: A case from Sweden and China. Computers $\mathcal{E}$ Education, 69, 169-180.

Wong, K., Wang, F. L., Ng, K. K., \& Kwan, R. (2015). Investigating acceptance towards mobile learning in higher education students. Transforming Educational Practices with Technology, 494, 9-19.

Xu, C., Ryan, S., Prybutok, V., \& Wen, C. (2012). It is not for fun: An examination of social network site usage. Information and Management, 49(5), 210-217.

Zedan, M., \& Salem, Y. (2016). Factors affecting consumer attitudes, intentions and behaviors toward SMS advertising in Palestine. Indian Journal of Science and Technology, 9(4), 1-14.

Zhu, D. H., \& Chang, Y. P. (2014). Investigating consumer attitude and intention toward free trials of technology-based services. Computers in Human Behavior, 30, 328-334. 
